\title{
Forensic medicine and its role in criminal justice in Palestine: insights for reform
}

\begin{abstract}
This report presents the reality of the Forensic Medicine in Palestine, and explores proposals for legal reform for the sake of enhancing criminal justice.
\end{abstract}

Keywords: forensic medicine, legal medicine, criminal justice, judicial proceedings, Palestinian judiciary, legal reform
Volume 5 Issue 3 - 2017

\section{Mahmoud Dodeen}

Assistant Professor, Faculty of Law and Public Administration, Birzeit University, Palestine

\section{Correspondence: Mahmoud Dodeen, Assistant Professor Faculty of Law and Public Administration, Birzeit University, Palestine, Tel 97 0597057078,Email mdodeen@birzeit.edu}

Received: August 04, 2017 | Published: August 29, 2017

\section{Introduction}

Forensic science plays a vital role in sustaining rule of law and enhancing criminal justice. Criminal investigations are performed through technical assistance to decide on whether a crime has been committed, when, how and by whom. The rights of defendant are also ensured by forensic services; by means of exonerating the innocent and corroborating a victim's evidence. Forensic evidence typologies are numerous including: fingerprints, hair, fiber, firearms, drug evidence, biological evidence, impression evidence, and entomological evidence. These typologies are supported by several legal entities in the State alongside the forensic departments. ${ }^{1}$ The Palestinian Penal Procedure Law No. 3 of 2001 has adopted few articles on admissible measures of proof-taking during the investigation or the trial including: fingerprints, palmprints, footprints, and all the reports issued by or officially approved and signed by the employee responsible for government laboratories, and which include the results of the chemical tests or analyses. The law also permits prosecutors to seek the assistance of competent physician and other experts to establish the conditions of the crime committed. This report presents the reality of Forensic Medicine in Palestine, and explores proposals for legal reform for the sake of enhancing criminal justice.

\section{Case report}

In Palestine, forensic Medicine services are limited to cases of mysterious death only. There is no standalone and independent entity that tackles forensic services. Nonetheless, there are three modest Forensic Medicine Centers in Palestine; two of these are located at An-najah and Alquds universities, while the other is headquartered in Al-Shifa Hospital in Gaza. In addition, neither national Criminal

${ }^{1}$ For more information see Mia. Abdur Rahim (2013) Role of Doctors in the Criminal Proceedings of Bangladesh with Special Reference to Women's Access to Justice, Journal Of Humanities And Social Science, 7 (5), pp. 43 51; Peterson, Joseph \& Sommers, Ira (2010) The Role and Impact of Forensic Evidence in the Criminal Justice Process, California State University, Los Angeles, at https://www.ncjrs.gov/pdffiles1/nij/grants/231977.pdf; Fahmy, Khaled (1999) The Anatomy of Justice: Forensic Medicine and Criminal Law in Nineteenth-Century Egypt, Islamic Law and Society, 6 (2), pp. 224-271; Edmond, Gary \& Roberts, Andrew (2011) Procedural Fairness, the Criminal Trial and Forensic Science and Medicine, Sydney Law Review, 33, pp. 359394; and Julian, Roberta et al. (2012) "Get it right the first time": Critical Issues at the Crime Scene, Current Issues in Criminal Justice, 24 (1), pp. 25-37.
Laboratories automated fingerprint identification system, nor national DNA index systemis in place yet. Hundreds of lawsuits are pending for a long time in the courts because of the lack of technical evidence for the abovementioned factors. The late Palestinian President Yasser Arafat issued decree No. (24) of 1994 to allow for establishing a centre for forensic medicine in accordance with a special law. The decree states that such centre should be administratively annexed to the Ministry of Justice and technically managed by Ministry of Health. Until now, a unified law to regulate the management of forensic medicine is still absent. ${ }^{2}$ Accordingly, the credibility of reports released by forensic medicine in Palestine is questionable due to the dominance of the Executive Authority of the State over the said centers. Ministers of health and justice exercise powers towards the forensic industry, and sometimes the security agencies intervene in the investigations and in the whole process, particularly in cases related to malpractices of its officers. ${ }^{3}$

According to the Palestinian Independent Commission for Human Rights, there is a great inconsistency in reports that reach the judiciary by forensic doctors. The opinions of these doctors are often excluded by courts, and replaced by reports prepared by private doctors. Moreover, the results of investigations and the results of the autopsy are not normally disclosed. ${ }^{4}$ In sum, despite the helpful rules provided for in the Palestinian Penal Procedure Law, forensic medicine in Palestine does not present significant services to the judiciary as it does not establish evidentiary facts to be beneficial; criminal justice, therefore, faces serious obstacles due to the lack of modern and transparent legal regulation of the forensic profession.

\section{Insights for reform}

To enhance criminal justice, forensic evidence should entail probative value, and must be sufficiently useful to prove scientific factors and elements of a crime collected at crime scenes in a trial;

${ }^{2}$ In 2011, the defacto government in Gaza has issued a law concerning forensic Medicine (this law does not apply in the West Bank).

${ }^{3}$ For more analysis see Al-Hadidi, Mu'men (2003) Forensic Science and its Role in Criminal Justice in Palestine, Institute of Law, Birzeit University, Ramallah, Palestine; and Al-Junaidi, Amer\& Al-Saadi, Osama (2010), Forensic Medicine in Palestine: reality and prospects, Report by the Institute of Law, Birzeit University, Ramallah, Palestine.

${ }^{4}$ The Palestinian Independent Commission for Human Rights, http://ichr.ps/ en/1/6. 
so as to build the emotional conviction of judges and promote public confidence. To this effect, the Palestinian legislature is recommending to issue a uniform law on forensic medicine. This law should address both the management and technical aspects of the matter in question. As for the management, we suggest establishing a Supreme Council of Forensic Medicine to ensure the independence and neutrality of forensic services from the government. Besides the membership of relevant public institutions in the board of management, the Council has to accommodate a majority of representatives from the Bar Association, Doctors Syndicate, academics, human rights institutions, prosecution and the judiciary. The Council shall serve as a sole authority in hiring and firing forensic doctors and experts. For the technical aspects, the law may regulate the crime scenes through criminal laboratory analysis, the relationship among stakeholders, including the institutions of justice sector, and then through subsequent criminal justice processes. The specifications and independence of laboratories as well as the accuracy and credibility of reports are key elements of the law. A fair appeal mechanism is advised to be effectively articulated in the law. Accountability and transparency measures are also of high significance for the credibility and stability of the forensic medicine sector. The government is required to furnish the Supreme Council with all needed recourses, and to create all supportive databases and networks of information necessary for the smooth functioning of the proposed council.

\section{Funding}

None.

\section{Acknowledgments}

None.

\section{Conflicts of interest}

The authors declare that here are no conflicts of interest. 